\title{
Romantic Jealousy and Love Infidelity Correlations
}

\author{
Thiago de Almeida ${ }^{1}$, Adriano Schlösser ${ }^{2}$ \\ ${ }^{1}$ Departamento de Psicologia da Aprendizagem, do Desenvolvimento e da Personalidade, Universidade de São \\ Paulo (USP), Instituto de Psicologia, São Paulo, Brazil \\ ${ }^{2}$ Departamento de Psicologia, Membro do Laboratório de Psicologia Social da Comunicação e Cognição \\ (LACCOS), Universidade Federal de Santa Catarina (UFSC), Santa Catarina, Brazil \\ Email: thiagodealmeida@thiagodealmeida.com.br
}

Received 12 July 2014; revised 13 August 2014; accepted 5 September 2014

Copyright (C) 2014 by authors and Scientific Research Publishing Inc.

This work is licensed under the Creative Commons Attribution International License (CC BY).

http://creativecommons.org/licenses/by/4.0/

(c) (i) Open Access

\begin{abstract}
Many researchers have studied the factors that can contribute to a loving relationship remaining stable and having a good quality for both partners. Two of the most worrying concerns that people have in regard to love relationships are the jealousy and infidelity. The purpose of this study was to verify whether there is relationship between these two phenomena. In this study, 45 heterosexual couples with an average age of 24.6 years participated, who were recruited through an ad placed on the site of a public university located in the city of Sao Paulo. To assess the degrees of jealousy of the participants, "Escala de ciúme romântico-ECR" was used. To evaluate the infidelity of the participants, the "Inventário de comportamentos relacionados à infidelidade" created specifically for this work was used. The results indicated that: 1) though it was so low, the jealousy is an agent of self-fulfilling prophecy for infidelity $(r=0.25,90 \mathrm{df}, p<0.05)$; and 2$)$ there is an association for the infidelity of each partner related to the infidelity of the other partner $(r=0.36, d f 45$, $p<0.05)$. These results indicate, therefore, that there is a direct relationship between the jealousy and infidelity.
\end{abstract}

\section{Keywords}

Jealousy, Infidelity, Love, Romantic Relationships

\section{Introduction}

Jealousy may be understood as a reaction to a threat coming from a rival to an important relationship (real or imaginary) (Costa, 2005; Kebleris \& Carvalho, 2006; Kingham \& Gordon, 2004). Hintz (2003) adds that jeal- 
ousy is part of a loving relationship.

According to Almeida (2007), jealousy can be dispositional and situational. The first occurs when both partners are exposed to similar situations and both feel jealousy in different intensities. For example, the fact that your girlfriend/boyfriend/partner still keeps in touch with his/her ex may be the trigger for one to terminate the relationship; while to another person, it may only trigger a light feeling of jealousy, which he/she is able to deal with in a peaceful way. On the other hand, situational jealousy is the feeling that allows a person to experience different intensities of jealousy in distinct situations.

The idea of being the only one on the eyes of his/her loved one crumbles when a third element presents itself as a threat-real or not- to the relationship. Hence, jealousy can be conceived as a reaction from affection experienced by an individual that perceives that the love, the affection and the attention of his/her partner are given to a third party when these opportunities should be offered to him/her (Almeida 2007; Almeida \& Rodrigues, 2008; Almeida, Rodrigues, \& Silva, 2008; Clanton \& Smith, 1998).

One of the widely accepted definitions of jealousy states that it is a "complex of thoughts, feelings and actions that follow threats to self-esteem and/or threats to the existence or quality of the relationship when those threats are generated by the perception of a real or potential attraction between one's partner and a (perhaps imaginary) rival” (White, 1981: p. 129). Jealousy and infidelity are some of the most disquieting worries of loving relationships (Almeida \& Lourenço, 2011; Pires, Abreu, Urbinati, De Tilio, \& Almeida, 2011; Roveri \& Almeida, 2008; Almeida \& Lourenço, 2011; Gomes, Amboni, \& Almeida, 2011; Sousa, Santos, \& Almeida, 2011). Even when the choice of a partner for a long-term relationship is not under discussion, many individuals fear that their partner will find other people potentially more attractive and gratifying, feeding an affective insecurity (Buss, 2000; Murray, Holmes, \& Griffin, 2000).

Taking in consideration that we do not directly perceive reality and that our perceptions are influenced by our expectations, beliefs, goals, values and emotions, it can be understood that the perception of one's own jealousy and the partner's infidelity will be idiosyncratic. However, it can be observed that feeling jealous is adequate and healthy to protect the loving relationship when the intensity is proportional to the risk that the situation brings. To a certain extent this jealousy manifestation can have a preventive or retaliating role when confronted with the threats to the loving relationship that could be provoked by the interference of a possible rival. The preventive function is constituted by measures that restrict the partner's exposure to a threatening situation (i.e. not going to places that might incite the involvement with possible rivals). The retaliating function is constituted by measures taken to punish the infidelity cases (to have an affair as well, or to end the relationship). So it can be assumed that jealousy is an inadequate reaction only when disproportional to the risks. In other words, jealousy becomes pathological when it causes anguish and damage to the loved one as well as the person that is feeling jealous. In this case the suspicions are unfounded; there are no reality data to support it. The pathological jealousy —obsessive, not psychotic —is made up by a series of irrational thoughts and emotions, by unjustified and irrational worry associated to unacceptable or extravagant behaviors, in which the prevailing theme is the concern with the infidelity of the partner.

Infidelities can cover a number of different manifestations and damage many loving relationships, like adultery for example. The infidelity is a genre in which adultery is only one kind of infraction. Infidelity, like jealousy, is not specific only to marital relationships, and can be found in other romantic contexts, like dating, engagement, and other forms of loving relationships (Goldenberg, 2006; Shackelford, Leblanc, \& Drass, 2000; Thompson, 1983, 1984).

Our behaviors are largely influenced, and even governed, by norms and/or expectations that function as directives for people to behave a certain way in a determined situation. The expectations about the behaviors can be transformed in self-fulfilling prophecies. These prophecies are beliefs that affect behaviors and increase the chances of that in which you believe or fear of occurring (Brophy, 1983; Copeland, 1994; Murray, Holmes, \& Griffin, 1996).

Therefore, would it be possible to consider the romantic jealousy as a self-fufilling prophecy of the love infidelity, similar to that conceived by Merton (1948) or by Rosenthal \& Jacobson (1968)? If so, would it be possible to assume that jealousy works similarly to a type of self-fulfilling prophecy that would induce the loss of quality on loving relationships, or even be one of the main reasons - on later stages - for the rupture of these relationships, inducing both partners to engage to infidelity related behaviors?

The goals of this research were: 1) to verify if there is an association between the jealousy degrees of the partners; 2) to verify if there was an association between jealousy and partner infidelity (sexual, emotional or 
both); 3) to verify if jealousy could act as an agent of the self-fulfilling prophecy for infidelity; 4) to identify if the infidelity (sexual, emotional or both) of one of the partners is related to the infidelity (sexual, emotional or both) of the other partner, both participants in this research.

\section{Method}

\subsection{Subjects}

Forty-five heterosexual couples participated on this research, with the age mean of 24.6 ( $s d=4.89$; male mean: 24.3; $s d=3.22$; female mean: 24.9 , $s d=6.24$ ), recruited by means of an add found on a website of an university located in São Paulo City. The research was done on a classroom of the university for those participants that could be present to answer the questionnaire. For those participants that could not be present the questionnaire was forwarded and answered through electronic mail (email). It is important to highlight that the present project was evaluated and accepted by the Ethics Committee, protocol number 062/04, which approved the execution of the later, following the required ethical proceedings for research with human beings.

\subsection{Instruments}

\subsubsection{Escala de Ciúme Romântico ${ }^{1}$ (ECR)}

Developed by Ramos, Yazawa and Salazar (1994), this scale is made up of 52 items that indicate degrees of jealousy. We used two versions: a questionnaire with male-adequate assertions and another with female-adequate assertions. The questionnaire assertions are classified into four categories: Acceptance (25 items); Pain (19 items); Anger (14 items); Non-threat versus threat (40 items).

Each assertion is accompanied by a five-point Likert Scale, varying from "completely disagree" (alternative 1) to "completely agree" (alternative 5). On this research we only used questions from the ECR that were part of the general factor "Non-threat versus threat" (Ramos, 2000) ${ }^{2}$. The measures of the answers to the questions were classified by the author into five crescent degrees of jealousy: minimum, light, moderate, intense and excessive.

\subsubsection{Inventory of Behaviors Related to Love Infidelity}

In order to capture what the participants conceive as behaviors related to infidelity (sexual, emotional or both) an instrument was elaborated. It has 35 items and four versions: one with assertions adequate for male participants, one with assertions adequate for female participants, one for ex-partners, and one for current partners.

We created a list with thirty behaviors apparently related to love infidelity (sexual, emotional or both), constructed from quotes: 1) heard in clinical sessions attended by the first author, 2) present in the scientific literature from this area, and 3) examples from a sample of 30 volunteers (15 men and 15 women). The task of this participant sample was describe feelings, behaviors and situations that they considered as potential or factual infidelity, either experienced by themselves or by people they knew.

This procedure resulted descriptions of thirty types of behavior related to love infidelity. The behavior types were submitted to a semantic analysis by means of the following procedure: the items were presented to 172 teenagers ( 86 boys and 86 girls) at a school in the same city where the participant sampling was done. The task of these participants was to either agree or disagree from the hypothesis of each item related to infidelity (sexual, emotional or both), and also volunteer other items, other than the existing thirty, that they thought related to infidelity (sexual, emotional or both). An item was eliminated from the initial list when at least $50 \%$ of the people, from at least one sex, disagreed that it would be related to an infidelity. A new item would be included in the list when at least two people cited a new type of infidelity. Using these procedures six assertions were excluded from the thirty original and eleven assertions were added totaling in 35 assertions that composed the final instrument.

\subsection{Data Collection}

The data collection was organized in two stages: 1) the in person and online application; and 2) application of the same procedure three months after the first stage.

During stage 1, after the participants got in contact with the experimenter interviews were scheduled for the

\footnotetext{
${ }^{1}$ Romantic Jealousy Scale.

${ }^{2}$ The forty items selected from the factor "Non-threat versus threat" that were analyzed for this paper were: 1, 2, 3, 6, 7, 8, 9, 10, 11, 13, 14, $16,18,19,20,21,22,24,25,26,28,29,30,31,32,33,34,36,37,38,39,40,41,42,44,46,47,50,51$ and 52.
} 
data collection. At the scheduled date, the individuals were separated into rooms to answer the questionnaire individually. The Informed Consent Form was distributed, and, if the terms were agreed upon, each participant received a set of tests (ECR and the Inventory of Behaviors Related to Love Infidelity Relating to the Current Partners). To mitigate possible response bias brought on by the order of applications of the tasks (order effects and carry over) a counterbalancing was done: the distribution of the questionnaires was done in an alternate manner: half of the participants answered the ECR first, and the other half answered the Inventory of Behaviors Related to Infidelity first. After the data collection the participants received a feedback which indicated the degree of jealousy appointed to them in their ECR.

As for the participants that could not be there in person, the application was done online. We sent the Informed Consent Term so that the participants could sign it and send it back to the researcher. Afterwards, the same set of tests applied personally on the participants were sent by email, with instructions attached, paying the same attention to counterbalance the order of the questionnaires.

The second stage occurred approximately three months after the first. In this stage the same procedure as the first stage was adopted. The goal of repeating this procedure was to verify the reliability of participant answers.

\subsection{Data Analysis}

The data from the first and second stage were processed separately. For the data analysis we used the following statistical tools: mean, standard deviation, maximum, minimum, Pearson's correlation, t-test to compare means. Excel and Minitab were used for statistical means.

\subsection{Variable Definition}

The data we collected was analyzed so to verify the existence of a possible relation between the variables "jealousy" and "infidelity".

To analyze the data referring to jealousy the results were divided into two kinds. The score for jealousy in the first stage of the research was labeled "Jealousy I" and it was obtained dividing the score by the number of items from the Threat versus Non-Threat factor of the ECR. The score "Jealousy II" was calculated the same way as "Jealousy I" based on the data collected on the second stage of the research.

To analyze the data referring to love infidelity, the variable "Infidelity I" was defined (infidelity characterized by the participants) and calculated by taking the raw score of infidelity related behaviors from each participant and dividing it by the relationship length declared by the participant (in months) on the first stage of the research. In the same manner, the variable "Infidelity II" (utilizing data from the second stage of the research) was calculated by taking the raw score of infidelity related behaviors from each participant and dividing it by the relationship length declared by the participant (in months).

The variable "Infidelity III" (infidelity characterized by the partners of the participants on the first stage of the study) was calculated by taking the raw score of infidelity related behaviors from each participant and dividing it by the relationship length declared by the participant (in months). The variable "Infidelity IV" (infidelity characterized by the partners of the participants on the second stage of the research) was calculated in the same manner, by taking the raw score of infidelity related behaviors from each participant and dividing it by the relationship length declared by the participant (in months).

\section{Results}

Pearson's Correlation was used to verify if the two measures of "Jealousy" (I and II), the "Infidelity" (I, II, III, IV) types amongst themselves, and both variables "Jealousy" and "Infidelity" were related somehow (Table 1). These correlations are as follows: the correlation between the two variables "Jealousy I" and "Jealousy II", independently of sex, was $r=0.87$ (90 df; $p<0.0001$ ). Taking this into consideration, we can consider there is a tendency for each participant to have the same jealousy score on both stages of the research (reliability test-retest).

Statistically significant correlations were observed between all measures of jealousy and between the two stages of the research. It was verified that there is no statistically significant difference between the jealousy measures, independently of participant sex, measured on the two stages of the research. For such conclusion a pared $\mathrm{T}$ test was used (t-test $\left.t_{89}=-0.13 ; p=0.898\right)$. 
Table 1. Correlations between jealousy measures measured on each stage and the research stages.

\begin{tabular}{ccccccc}
\hline \multirow{2}{*}{ Jealousy types of and participant sex } & \multicolumn{2}{c}{ Jealousy I } & \multicolumn{2}{c}{ Jealousy II } \\
\cline { 3 - 6 } & Men & men & women & men & women \\
\hline \multirow{2}{*}{ Jealousy I } & Women & 0.50 & $0.50^{*}$ & 0.82 & $0.53^{* * *}$ \\
& Men & $0.82^{* * *}$ & $0.46^{* * * *}$ & 0.46 & 0.91 \\
\multirow{2}{*}{ Jealousy II } & Women & 0.53 & 0.91 & $0.52^{* * * * *}$ & 0.52 \\
& W & &
\end{tabular}

*45 df; $p<0.001 .{ }^{* *} 45 d f ; p<0.001 .{ }^{* * *} 45 d f ; p<0.001 .{ }^{* * * *} 45 d f ; p<0.001 .{ }^{* * * * * *} 45 d f ; p<0.001$.

All the possible correlations between all the measures of jealousy (on the first and second stage, for men and women) and the four types of infidelity (infidelity of the participants and partners, on first and second stage) were calculated. Due to a space issue, only the statistically significant correlations will be presented in this paper, obtained through this procedure: 1) Correlation between the variables "Infidelity I" and "Infidelity II" for men was $r=0.36$ (45 $d f ; p=0.015)$; 2) Correlation between the variables "Jealousy I" and "Infidelity IV”, independently of sex, was $r=0.248$ (90 df; $p=0.018$ ).

It can be observed that on the second stage of the research the infidelity for men was correlated to the infidelity for women, even if only slightly ( $r=0.364 ; 45 d f ; p=0.014)$. Taking this into consideration, it might be that those who engage on infidelity related behaviors are associated to partners that also have personal motives to engage on infidelity related behaviors, or even there is a possibility that partners that have the tendency to cheat select others with the same tendency. Other possible causes for this would be the decrease of the veracity between partners and the tendency to retaliate the partner when the infidelity is discovered.

\section{Male and Female Jealousy of the Researched Sample}

There were no statistically significant differences between the means of jealousy measured on the first and second stage of the research (Paired t-test $t_{89}=-0.13 ; p=0.898$ ), between the means of male participants (Paired t-test $t_{44}=-1.10 ; 44 d f ; p=0.279$ ), nor between the means of the female participants (Paired t-test $t_{44}=$ $1.15 ; 44 d f ; p=0.258)$.

\section{Discussion}

The weight that loving relationships assume on contemporaneous people's lives is broad, taking on a highlighted place in the intimate life (Almeida, 2004; Almeida, 2013). However, this importance is only perceived when the relationship is not satisfactory (Nóbrega, Fontes, \& Paula, 2005), having jealousy and infidelity be some of the most frequent motives of disagreements between couples as suggested by Almeida (2008); Almeida, T. (2012); Almeida \& Centeville, (2008); Almeida \& Lourenço (2011); Almeida \& Rodrigues, (2008), Almeida, Rodrigues, \& Silva (2008).

The love infidelity is also a pertinent theme on the loving relationship universe. It can be noticed on infidelity, like on jealousy, that there is a distance between attitudes and behavioral values, such as seen by Goldenberg (2006). This study evaluated the associations between jealousy and infidelity, amongst other factors that might result into positive and negative consequences to the loving relationship.

When it comes to jealousy, we could verify that a high reliability test-retest $(r=0.88)$ was obtained, as well as verify that people that feel more jealous probably relate to partners as jealous as they are; and people that feel less jealous tend to attract partners that feel less jealous.

Since self-fulfilling prophecies are briefly defined as beliefs with potential to exert influence over the other, in a way that $\boldsymbol{B}$ might engage in some behavior or even change some attitude according to what $\boldsymbol{A}$ wishes (Copeland, 1994; Murray, Holmes, \& Griffin, 1996) it can be supposed that jealousy is a self-fulfilling prophecy according to the theory that Rosenthal \& Jacobson (1968) and Merton (1948) conceived. In other words, there are some affective-sexual situations where an alienating and possessive jealousy feeling takes over and leads to an interference and molestation of the partner's freedom, which is the target of this exaggerated affection that could result in elements of gradual distancing between the couple.

Therefore, the fear of losing the loved one drives infidelity to occupy a highlighted spot on the affective-sex- 
ual relationship's space. Cases can be observed where the jealous person tries to force the partner to sacrifice his/her self-confidence to level the relationship, and might scare themselves, for example, when the partner finds a job, activities and relationships that make her more confident and less dependent on them (Almeida \& Centeville, 2008). These situations might act on the separating motivation of the woman that feels hampered in her personal freedom and cannot see reason in maintaining a loving relationship which develops into a jealous and untrusting climate.

In this study, a modest relation between primary beliefs, which underlie jealousy, and the relationship's future can be suggested. This might be because when doubts start to be hyper-dimensioned and super valued the individual is compelled to verify if his/her doubts are or not coherent to his/her expectations, getting into a delirious cycle of fears and distrust. Therefore, even if subtly, the jealous person starts to make the loved one hostile having the indissolubility of the bond as a goal.

These attitudes, in many occasions, are not identified as forms of zeal and affection by those whom manifest it, and, above all, by those who suffer the diverse nuances of this feeling that, at times, might translate into physical and psychological violence (Centeville \& Almeida, 2007; Almeida \& Centeville, 2008; Almeida, 2008). In these situations, the intimidated partners, put in a state of need, learn to escape from the relationship and count with, many times, with the help of a new sentimental adventure that promises to develop without all the imperfections from the current relationship.

In other situations infidelity relationships can psychologically collaborate to the regulation of the marriage stability, in this case functionally serving as relationship survival trial, either due to the person being less assertive and not putting him/herself against the partner, or due to not feeling strong enough to end the current relationship worn out by jealousy (e.g. Sousa, Santos, \& Almeida, 2009).

It was verified in this research that the jealousy scores from the first stage are directly correlated to the infidelity scores by the partners from the second stage ( $r=0.248$; $90 d f ; p=0.018)$. For this reason we can infer that as the jealousy of each of the participant's increases, so does the chance of becoming the target of his/her partner's infidelity, as was envisaged by the self-fulfilling prophecy related to the infidelity of the other partner. Therefore, the person would be able to model the loving behavior of the partner.

Accordingly, this research's results suggest that the jealousy is associated to the love infidelity of the partner, such as would be predicted by the self-fulfilling prophecy (Rosenthal \& Jacobson, 1968). Another hypothesis is that those who feel more jealous read beforehand the indicators that the partner was willing to be unfaithful. It is even possible to question these findings with the claim that the instrument used to collect the data in this research could have provoked a reactive effect. According to this reasoning, the pre-test could have influenced the sensibility, or even the capacity of inducing a higher degree of partner vigilance, which would have made each participant more attentive to the infidelities that were going on at the time, compromising the internal validity of the instrument.

However, there is some evidence to weaken this hypothesis. Firstly, if the instrument used on the research did induce the behavior of vigilance on the participants, in the other hand it probably should have had similar effects on those who were thinking about cheating, making them hide even more their own infidelity, or even cheat less. Another objection to that hypothesis is that the infidelity was not fruit from the partner's perceptions but reported by the perpetrators, and induced by them. Care was taken to reduce other experimental biases, such as secrecy of the information obtained, anonymity of participants, collection of data in specific rooms, at separate moments, amongst other measures.

\section{Final Considerations}

The main purpose of this study was to determine if there was any relation between infidelity behaviors and jealousy scores. When it comes to the love infidelity theme, it is usual to look towards the "unfaithful partner" and victimize the person that was cheated on. The goal of this paper was not to determine cause and effect relations between those two variables, plausibly justify betrayals, or even dislocate the guilt of infidelity to the person that was cheated on. The goal was to ascertain the possible contributions of each part of the loving relationship on the composition of the final configuration on the infidelity frame.

At some point in their lives, it is common for people to look for a partner with whom they can share affection, happiness, pleasure, companionship, sex, amongst other aspects. It so happens that when people adhere to loving relationships and this search persists by means of infidelities, it could cause much damage to all those involved 
including relatives and friends that follow the relationship. Probably due to this damage, the romantic jealousy was a mechanism positively selected to prevent loving relationships from the harms of an eventual infidelity.

According to Almeida (2007), jealousy in right dosages would strengthen the stability of a loving relationship, together with other factors. It is important to point out that a complete lack of jealousy is also harmful to a loving relationship, for it generally implicates on a low adherence of at least one of the parties involved.

Aside from the self-fulfilling prophecy mediated by the jealousy, it is evident that there are other causes of infidelity, even if they have not yet been mentioned by the present study. There is little known about which partners are more suited to infidelity, but this study allowed us to identify factors that promote infidelity.

Although this research presented evidence that jealousy acts, to some extent, as a self-fulfilling prophecy of infidelity, a question still remains: taking in consideration jealousy's subjectivity, what is the ideal dosage of jealousy so that people could feel it and consequently take care of the loving relationships without, however, damaging it? This questioning remains for future researches.

\section{References}

Almeida, T. (2004). A gênese e a escolha no amor romântico: alguns princípios regentes. Revista de Psicologia (Fortaleza), 22, 15-22.

Almeida, T. (2007). Ciúme romântico e infidelidade amorosa entre paulistanos: incidências e relações. Dissertação de Mestrado não publicado. Instituto de Psicologia, Universidade de São Paulo, São Paulo.

Almeida, T. (2008). A violência no namoro. In 6 Jornada APOIAR. Saúde Mental e Violência: Contribuições no campo da Psicologia Clínica (pp. 136-146). São Paulo: IPUSP.

Almeida, T. (2012). O ciúme romântico atua como uma profecia autorrealizadora da infidelidade amorosa? Estudos de Psicologia (PUCCAMP Impresso), 29, 489-498.

Almeida, T. (2013). Gestão por Processos, qualidade de vida e importância do amor nos relacionamentos afetivos são fatores relevantes no cotidiano das pessoas. Psique (São Paulo), 86, 22-23.

Almeida, T., \& Centeville, V. (2008). Propostas psicoterapêuticas para vítimas do ciúme patológico. In 6 Jornada Apoiar: Saúde Mental e Violência: Contribuições no campo da Psicologia Clínica (pp. 170-180). São Paulo: IPUSP.

Almeida, T., \& Lourenço, M. L. (2011). Ciúme romântico: um breve histórico, perspectivas, concepções correlatas e seus desdobramentos para os relacionamentos amorosos. Revista de Psicologia, 2, 18-32.

Almeida, T., \& Rodrigues, K. R. B. (2008). Mitos da infidelidade. Psique, 33, 70-79.

Almeida, T., Rodrigues, K. R. B., \& Silva, A. A. (2008). O ciúme romântico e os relacionamentos amorosos heterossexuais contemporâneos. Estudos de Psicologia (Natal), 13, 83-90.

Brophy, J. (1983). Research on the self-fulfilling prophecy and teacher expectations. Journal of Educational Psychology, 76, 236-247.

Buss, D. (2000). Dangerous Passion: Why Jealousy Is as Necessary as Love and Sex. Darby, PA: Diane Pub Co.

Centeville, V., \& Almeida, T. (2007). Ciúme romântico e a sua relação com a violência. Psicologia Revista, 16, 71-89.

Clanton, G., \& Smith, L. G. (1998). Jealousy. New York: University Press of America.

Copeland, J. T. (1994). Prophecies of Power: Motivational Implications of Social Power for Behavioral Confirmation. Journal of Personality and Social Psychology, 67, 264-277. http://dx.doi.org/10.1037/0022-3514.67.2.264

Costa, N. (2005). Contribuições da psicologia evolutiva e da análise do comportamento acerca do ciúme. Revista Brasileira de Terapia Comportamental e Cognitiva, 1, 5-13.

Goldenberg, M. (2006). Infiel: Notas de uma antropóloga. Rio de Janeiro: Record.

Gomes, A. L., Amboni, G., \& Almeida, T. (2011). Ciúme romântico em casais heterossexuais: Relatos de pessoas casadas e unidas consensualmente. Pensando Famílias, 15, 31-50

Hintz, H. C. (2003). O Ciúme no processo amoroso. Pensando Famílias, 5, 45-55.

Kebleris, F., \& Carvalho, L. F. (2006). Investigação de uma estrutura para o ciúme romântico e sua manifestação patológica. Trabalho de Conclusão de Curso. São Paulo: Universidade Presbiteriana Mackenzie.

Kingham, M., \& Gordon, H. (2004). Aspects of Morbid Jealousy. Advances in Psychiatric Treatment, 10, 207-215. http://dx.doi.org/10.1192/apt.10.3.207

Merton, R. K. (1948). The Self-Fulfilling Prophecy. Antioch Review, 8, 193-210. http://dx.doi.org/10.2307/4609267

Murray, S. L., Holmes, J. G., \& Griffin, D. W. (1996). The Self-Fulfilling Nature of Positive Illusions in Romantic Relationships: Love Is Not Blind, but Prescient. Journal of Personality and Social Psychology, 71, 1155-1180. 
http://dx.doi.org/10.1037/0022-3514.71.6.1155

Murray, S. L., Holmes, J. G., \& Griffin, D. W. (2000). Self-Esteem and the Quest for Felt Security: How Perceived Regard Regulates Attachment Processes. Journal of Personality and Social Psychology, 78, 478-498. http://dx.doi.org/10.1037/0022-3514.78.3.478

Nóbrega, S. M., Fontes, E. P. G., \& Paula, F. M. S. M. (2005). Do amor e da dor: Representações sociais sobre o amor e o sofrimento psíquico. Estudos Psicologia (Campinas), 22, 77-87. http://dx.doi.org/10.1590/S0103-166X2005000100009

Pires, M. R. M., Abreu, M., Urbinati, M. C., De Tilio, R., \& Almeida, T. (2011). Representações dos homens heterossexuais acerca do ciúme contemporâneo. In 3 Simpósio Brasileiro de Família e Desenvolvimento Humano: Prevenção, intervenção e promoção da saúde psicológica (pp. 123-124). Curitiba: UFPR.

Ramos, A. L. M. (2000). Ciúme romântico: Teoria e medida psicológicas. São Paulo: Stiliano.

Ramos, A. L. M., Yazawa, S. A. K., \& Salazar, A. F. (1994). Desenvolvimento de uma escala de ciúme romântico. Psicologia: Teoria e Pesquisa, 10, 439-451.

Rosenthal, R., \& Jacobson, L. (1968). Pygmalion in the Classroom: Teacher Expectations and Pupil's Intellectual Development. New York: Holt, Rinehart and Winston.

Roveri, P. M., \& Almeida, T. (2008). Ciúme: O inferno do amor possessivo, uma análise sob a perspectiva da tríplice contingência. In 6 Jornada APOIAR: Saúde Mental e Violência: Contribuições no campo da Psicologia Clínica (pp. 526-542). São Paulo: IPUSP.

Shackelford, T. K., LeBlanc, G. J., \& Drass, E. (2000). Emotional Reactions to Infidelity. Cognition and Emotion, 14, 643659. http://dx.doi.org/10.1080/02699930050117657

Sousa, D. L., Santos, R. B., \& Almeida, T. (2009). Vivências da infidelidade conjugal feminina. Pensando Famílias, 13, 197214.

Sousa, D. L., Santos, R. B., \& Almeida, T. (2011). Vivências da infidelidade conjugal feminina. In 3 Simpósio Brasileiro de Família e Desenvolvimento Humano: Prevenção, intervenção e promoção da saúde psicológica (pp. 117-119). Curitiba: UFPR.

Thompson, A. P. (1983). Extramarital Sex: A Review of the Research Literature. Journal of Sex Research, 19, 1-22. http://dx.doi.org/10.1080/00224498309551166

Thompson, A. P. (1984). Emotional and Sexual Components of Extramarital Relations. Journal of Marriage and the Family, 46, 35-42. http://dx.doi.org/10.2307/351861

White, G. L. (1981). Some Correlates of Romantic Jealousy. Journal of Personality, 49, 129-145.

http://dx.doi.org/10.1111/j.1467-6494.1981.tb00733.x 
Scientific Research Publishing (SCIRP) is one of the largest Open Access journal publishers. It is currently publishing more than 200 open access, online, peer-reviewed journals covering a wide range of academic disciplines. SCIRP serves the worldwide academic communities and contributes to the progress and application of science with its publication.

Other selected journals from SCIRP are listed as below. Submit your manuscript to us via either submit@scirp.org or Online Submission Portal.
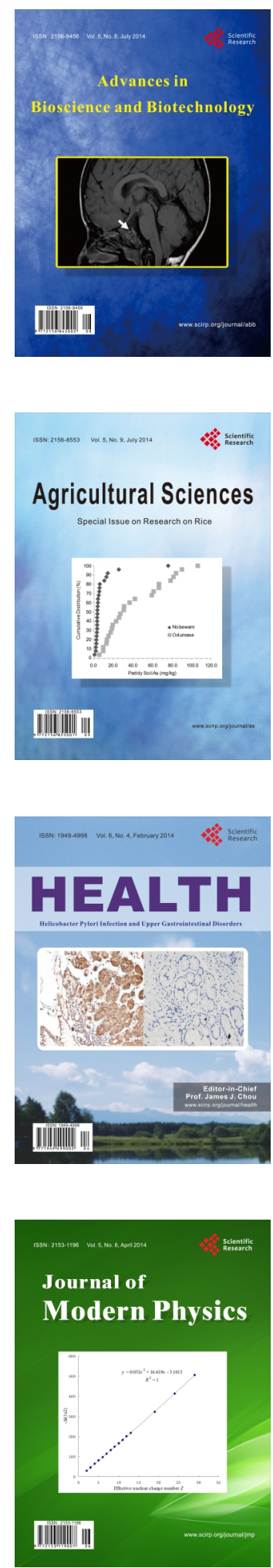
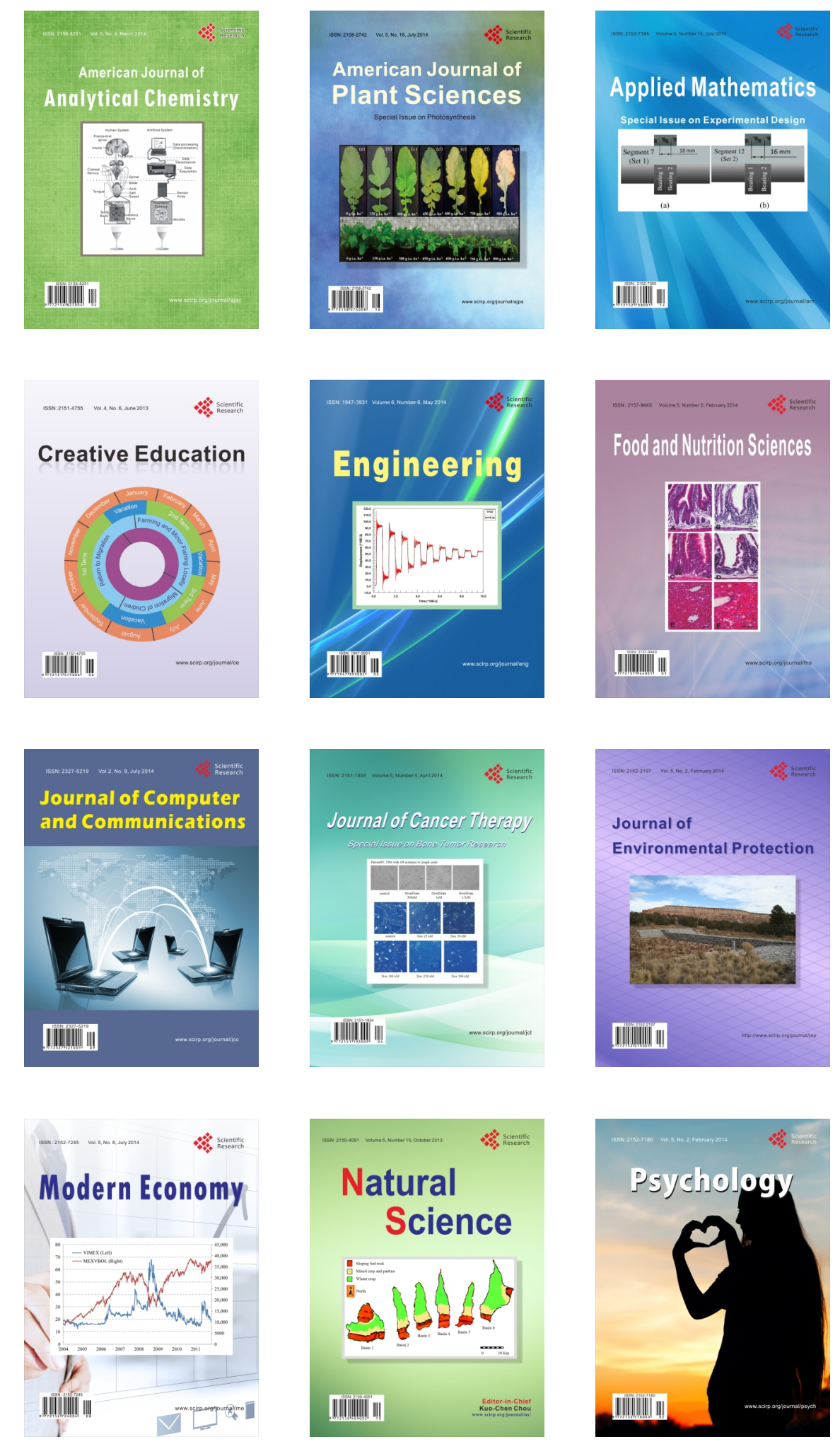